\title{
Gender and Violence in Cape Slave Narratives and Post-Narratives ${ }^{1}$
}

\author{
JESSICA MURRAY \\ University of Johannesburg
}

\begin{abstract}
:
Although most slaves' experience of slavery is lost to posterity, in some cases historians are fortunate enough to work with so-called slave narratives. The existence of many criminal court cases enables the historian to hear the voice of the slave clearly - albeit briefly and under strained circumstances. Recently some work has been done on these slave cases, but not in terms of narratives. Likewise, there is a new interest in postnarratives dealing with Cape slavery, but nobody has as yet connected these modern reincarnations with the earlier historical narratives. This article, then, explores Cape slave narratives and post-narratives by focusing on the ways in which the bodies of slave women become the sites on which both physical and discursive violence is enacted. The nature of available texts necessitates a reading strategy that teases out information from the gaps and silences in the narratives in an attempt to reveal the variegated texture of the lived experience of slave women in eighteenth-century South Africa. The article demonstrates how the violent experiences of slave women, and the resultant trauma, complicate a clear-cut distinction between fact and fiction. Through a juxtaposition of court records and a fictional post-narrative, the article uses a literary reading to access women's stories.
\end{abstract}

\section{Keywords:}

Violence; trauma; gender; slave women; bodies; Cape slave narratives

\section{Introduction}

Although most slaves' experience of slavery is lost to posterity, in some cases historians are fortunate enough to work with so-called slave narratives. In the United States, much scholarly activity has focused on the analysis of contemporary slave (auto)biographies and the Works Progress Administration (WPA) life narratives, as well as post-narratives (contemporary literary works based on the slave experience). Unfortunately similar sources do not exist for the study of slavery at the Cape of Good Hope. However, the existence of many criminal court cases enables the historian to hear the voice of the slave clearly - albeit briefly and under strained circumstances. There is an emerging body of

I am most grateful to Gerald Groenewald for the many insights and patient feedback he contributed during the process of writing this article. My thanks go also to Nicholas Southey for his valuable comments during the writing workshop at the 'Breaking Boundaries, Blurring Borders Conference' of the South African Historical Society, University of South Africa, June 2009. 
literature on these slave cases, but not in terms of narratives. ${ }^{2}$ Likewise, there is a new interest in post-narratives dealing with Cape slavery, but nobody has as yet connected these modern reincarnations with the earlier historical narratives. ${ }^{3}$ This article, then, explores Cape slave narratives and post-narratives by focusing on the ways in which the bodies of slave women become the sites on which both physical and discursive violence is enacted.

History has long moved beyond linear accounts of conflicts and territories to include the experiences of those who have been located at the peripheries of societies and cultures. ${ }^{4}$ Although some work has been done on gender and slavery in Dutch South Africa, this has mostly concentrated on the nineteenth-century experience while the eighteenth-century remains virtually unexplored. ${ }^{5}$ This article will illustrate that the stories of slave women's experiences of violence continue to be vulnerable to elision. By reading selected eighteenth-century criminal records from the Cape of Good Hope, in which women's experiences are briefly voiced (albeit under exceptional, often violent, circumstances), I will show how these texts 'prise open hidden worlds and interior

2 See N. Penn, Rogues, Rebels and Runaways: Eighteenth-Century Cape Characters (Cape Town: David Philip Publishers, 1999), 9-72; N. Penn, 'The Wife, the Farmer and the Farmer's Slaves: Adultery and Murder on a Frontier Farm in the Eighteenth Century', Kronos, 28 (2002), 1-20; K. Thomson, "The Mistress will be Consumed": A Study of Slave Resistance in $18^{\text {th }}$ Century Cape Town', Historical Approaches, 2 (2003), 16-29; S. Koolhof and R. Ross, 'Upas, September and the Bugis at the Cape of Good Hope: The Context of a Slave's Letter', Archipel, 70 (2005), 281308; G. Groenewald, 'Panaij van Boegies: Slave - Bandiet - Caffer', Quarterly Bulletin of the National Library of South Africa, 59 (2005), 50-62; F. Vernal, "No Such Thing as a Mulatto Slave": Legal Pluralism, Racial Descent and the Nuances of Slave Women's Sexual Vulnerability in the Legal Odyssey of Steyntje van de Kaap, c. 1815-1822', Slavery and Abolition, 29 (2008), 23-47.

3 See J. Murray, 'When Good Mothers Kill: A Representation of Infanticide', Agenda, 76 (2008), 32-41; M. Samuelson, 'Lose your Mother, Kill your Child: The Passage of Slavery and its Afterlife in Narratives by Yvette Christiansë and Saidiya Hartman', English Studies in Africa (forthcoming); R. Jacobs, The Slave Book (Cape Town: Kwela Books, 2007); M. Samuelson, "Castaways" and "Generations": Yvette Christiansë's Oceanic Genealogies and the Colonial Archive' (unpublished paper). A much larger literature exists on the literary representations of Khoi women, most notably those of Krotoa and Sarah Baartman.

4 R.R. Warhol and D. Price Herndl, 'History', in R.R. Warhol and D. Price Herndl, eds, Feminisms: An Anthology of Literary Theory and Criticism (New Jersey: Rutgers University Press, 1997), 855.

5 See P. van der Spuy, 'Gender and Slavery: Towards a Feminist Revision', South African Historical Journal, 25 (1991), 184-195; P. van der Spuy, 'Slave Women and the Family in Nineteenth-Century Cape Town', South African Historical Journal, 27 (1992), 50-74; P. van der Spuy, 'A Collection of Discrete Essays with the Common Theme of Gender and Slavery at the Cape of Good Hope with a Focus on the 1820s' (MA thesis, University of Cape Town, 1993); P. van der Spuy, "What Then was the Sexual Outlet for Black Males?": A Feminist Critique of Quantitative Representation of Women Slaves at the Cape of Good Hope in the Eighteenth Century', Kronos, 23 (1996), 43-56; P. Scully, 'Rape, Race and Colonial Culture: The Sexual Politics of Identity in the Nineteenth-Century Cape Colony, South Africa', American Historical Review, 100 (1995), 335-359; J. Mason, Social Death and Resurrection: Slavery and Emancipation in South Africa (Charlottesville, VA: University of Virginia Press, 2003); Vernal, 'No Such Thing as a Mulatto Slave', 23-47. 
landscapes of pain and oppression'.6 More specifically, the article will expose the extent to which these landscapes are shaped by gender and the reality of gender violence.

The nature of available texts necessitates a reading strategy that teases out information from the gaps and silences in the narratives in an attempt to reveal the variegated texture of the lived experience of slave women in eighteenth-century South Africa. The article will then consider a post-narrative in which Yvette Christiansë offers a fictionalised account of the story of the slave Sila van den Kaap in her novel Unconfessed, one of a number of recent slave post-narratives dealing with the Cape. ${ }^{7}$ The juxtaposition of court records and fiction will grapple with the continuing difficulties of representing women's experiences of violence and of articulating a comprehensive account of women's history. It will emerge from the article that the nature of patriarchy and violence ensures that narratives will rarely yield information of gender violence with ease. Instead, texts need to be prised open to access women's stories. In this way, the article combines historical research and investigation with literary analysis in order to arrive at a greater understanding of the relationship between slavery, gender and violence.

\section{Accessing the History of Slave Women: Challenges and Opportunities}

Nigel Worden notes that the history of the Cape during the period of Dutch East India Company (VOC) rule from 1652 to 1795 remains relatively unexplored, as most research focuses on the post-1800 era. ${ }^{8}$ If the eighteenth-century Cape is poorly represented in the annals of history, the experiences of women during this period is rendered doubly invisible. Patricia van der Spuy has argued that there is a dearth of historical attention to women and empire, and that in the history of the colonial Cape, women 'are barely visible'. When one considers that women of colour are located in at least two

$6 \quad$ R. Turrell, 'The "Singular" Case of Mietjie Bontnaal, the Bushmanland Murderess', Journal of Southern African Studies, 29 (2003), 84.

$7 \quad$ For example, A. Brink, Instant in the Wind (London: William Morrow, 1977); Jacobs, The Slave Book; T. Benadé, Kites of Good Fortune (Cape Town: David Philip, 2004); R. Brownlee, Garden of the Plagues (Cape Town: Human and Rousseau, 2005).

8 N. Worden, 'New Approaches to VOC History in South Africa', South African Historical Journal, 59 (2007), 3.

$9 \quad$ Van der Spuy, 'What Then was the Sexual Outlet', 43. Van der Spuy made this argument in the mid 1990s. Since then, growing attention to women and empire by many historians across the discipline has begun to change the landscape, although much work remains to be done; but Van der Spuy's argument remains valid when it comes to the history of women in the Cape during the eighteenth century. More historians of the Cape have focused on the experiences of women during the slave period at the Cape, but the bulk of these writings continue to deal with the nineteenthcentury. See, for example, Y. Abrahams, 'Disempowered to Consent: Sara Bartman and Khoisan Slavery in the Nineteenth-Century Cape Colony and Britain', South African Historical Journal, 35 (1996), 89-114; R. Holmes, The Hottentot Venus: The Life and Death of Saartjie Baartman: Born 1789 - buried 2002 (London: Bloomsbury, 2007); C. Crais and P. Scully, Sara Baartman and the Hottentot Venus: A Ghost Story and a Biography (Johannesburg: Wits University Press, 2009); H. Bradford, 'Women, Gender and Colonialism: Rethinking the History of the British Cape Colony and its Frontier Zones, c. 1806-70', The Journal of African History, 37 (1996), 351-370; P.D. Gqola, "Like Three Tongues in One Mouth": Tracing the Elusive Lives of Slave Women in (Slavoctratic) South Africa', in N. Gasa, ed., Women in South African History: They Remove Boulders and Cross Rivers (Cape Town: HSRC Press, 2007), 21-41; V.C. Malherbe, 'In Onegt Verwekt: Law, Custom and Illegitimacy in Cape Town, 1800-1840', Journal of Southern African Studies, 31 (2005), 163-185. For an analysis of the relations between masters and servants on the 
marginalised groups, namely those constituted by gender and race, the invisibility of slave women's experiences becomes even more apparent. ${ }^{10}$

In order to counter this invisibility, Yvette Christiansë's reading strategy proves useful for researchers who are interested in uncovering the experiences of slave women in the eighteenth-century Cape:

So there I was, rattling my chains in the colonial archive, and I began to learn to look sideways. [....] and everywhere I went, I found silence. So I began to pay attention to the silence, because I thought that the silence in some ways stenciled out the conditions in which [slave women] lived. ${ }^{11}$

In the court records that I analyse, women's voices are mostly silent and they tend to be mentioned in the narratives of either male slaves or of slave owners. However, women's experiences from their own perspectives continue to have consequences even when they remain unarticulated, and they certainly leave their traces in the texts. ${ }^{12}$ Dana Shiller contends that conceding that the past is only accessible via its textual traces does not imply that history is either impossible to retrieve or not worth salvaging. ${ }^{13}$ Indeed, 'although historical rigor may take on new meaning, it continues to have value, and remains compatible with approaches to history that accept the existence of many possible narratives for any given set of historical facts'. ${ }^{14}$

Hayden White's work on the impossibility of maintaining a clear-cut distinction between fact and fiction has been particularly influential in contemporary understandings of historiography. ${ }^{15}$ When we read historical narratives, we need to be cautious of the 'category mistake' involved in confusing a narrative version of events with a literal version of events. ${ }^{16}$ Narratives are always figurative and, by ignoring the figurative elements in a reading of narratives, we can miss a great deal of the meaning that is contained therein. Much can thus be gained from a literary reading of historical records, and it is as possible for important insights to be located in fiction as in historical records.

Cape eastern frontier in the latter part of the eighteenth-century, see S. Newton-King, Masters and Servants on the Cape Eastern Frontier, 1760-1803 (Cambridge: Cambridge University Press, 1999). For a fictionalised engagement with these issues, see the novel by B. Chase-Riboud, Hottentot Venus (New York: Anchor Books, 2004). K. Crenshaw, 'Mapping the Margins: Intersectionality, Identity Politics, and Violence against Women of Color', Stanford Law Review, 43 (1991), 1244.

11 Y. Christiansë, 'Interview', available at http://www.pbs.org/kcet/tavissmiley/archive/200702/20070215_christianseuml.html [accessed 29 May 2009].

D. Shiller, 'The Redemptive Past in the Neo-Historical Novel', Studies in the Novel, 29 (1997), 547.

Ibid., 541.

Ibid.

H. White, Metahistory: The Historical Imagination in Nineteenth-Century Europe (Baltimore: John Hopkins University Press, 1973). For more on the porosity of the fact/fiction division, see K. Murray, 'Fiction, History and Empirical Reality', Critical Inquiry, 1,2 (1974), 335-360; L. Hutcheon, A Poetics of Postmodernism: History, Theory, Fiction (New York: Routledge, 1988); R. Walsh, 'Fictionality and Mimesis: Between Narrativity and Fictional Worlds', Narrative, 11 (2003), 110-212; L. Mink, 'History and Fiction as Modes of Comprehension', New Literary History, 1 (1970), 541-558.

16 H. White, 'The Question of Narrative in Contemporary Historical Theory', History and Theory, 23 (1984), 24. 
The porosity of the border between fact and fiction is especially acute when one reads testimonies. The nature of testimonies becomes relevant here, since the court records analysed in this article provide us with the testimonies of slaves in courts of law. In their introduction to Trials of Slavery, ${ }^{17}$ Worden and Gerald Groenewald note that accused people were interrogated when they did not confess to crimes. The evidence that had been collected served as the basis for interrogation. Jacques Derrida argues that, although the terms 'fiction', 'testimony' and 'evidence' seem incommensurable, they are in fact intrinsically linked. The difficulty with linking these concepts arises from the fact that they belong to apparently incompatible cognitive systems. Fiction is associated with the imagination, testimony is linked to experience or observation, while evidence carries connotations of something that can rationally and scientifically serve to indicate veracity.

The notion of testimony is implicitly linked to an appeal to be believed. As soon as testimony gains the status of certainty, it changes from being testimony to being proof. Derrida thus explains that testimony "will always suffer both having, undecidably, a connection to fiction, perjury, or lie and never being able or obligated - without ceasing to testify - to become a proof'. ${ }^{18}$ Before something achieves the status of proof, it contains the possibility that it may be a lie. For this reason Derrida argues that there is 'no testimony that does not structurally imply in itself the possibility of fiction, simulacra, dissimulation, lie, and perjury'. ${ }^{19}$ In other words, these possibilities of fiction and lies enable testimony. If these possibilities were absent, one would have proof and the term testimony would become superfluous. When there is proof, there is no need to appeal to be believed, since the existence of proof of a statement means that the veracity of that statement has been established.

A further layer is added to the interpretive challenge when one reads testimonies to traumatic events, as was often the case with the violent events recounted in the court cases. Trauma results in traumatised individual and collective identities that pose particular challenges to representation. These representational difficulties make historical fiction particularly useful in articulating traumatic pasts. Dori Laub reminds us: 'Massive trauma precludes its registration; the observing and recording mechanisms of the human mind are temporarily knocked out, malfunction. ${ }^{20}$ All testimonies thus begin with a victim attempting to articulate something that has not yet come into being or, in other words, something that has, due to the flooding of the mind, not been fully experienced. This is in no way to deny that the event that caused the trauma has in fact taken place. Rather, the point being made is that the event is available to the victim only as an 'overwhelming shock' or something that exceeds her frame of reference. ${ }^{21}$ It is not yet

$17 \quad$ N. Worden and G. Groenewald, eds, Trials of Slavery: Selected Documents Concerning Slaves from the Criminal Records of the Council of Justice at the Cape of Good Hope, 1705-1794 (Cape Town: Van Riebeeck Society for the Publication of South African Historical Documents, 2005). J. Derrida, trans. E. Rottenberg, Demeure: Fiction and Testimony (Stanford: Stanford University Press, 2000), 28.

19 Ibid., 29.

20 D. Laub, 'Bearing Witness or the Vicissitudes of Listening', in S. Felman and D. Laub, eds, Testimony: Crises of Witnessing in Literature, Psychoanalysis and History (London: Routledge, 1992), 57.

$21 \quad$ Ibid. 
what Laub refers to as a 'known event'. These factors mean that trauma poses particular representational and temporal challenges. ${ }^{22}$

Trauma, with its temporal elusiveness, is not something that is available to the victim as a coherent, linear narrative. The text that is best able to articulate trauma is thus one that 'should register, in the form of its language, the gaps in memory and logic that thwart narrative coherence and linear chronology'. ${ }^{23}$ I make these points about the dynamics of trauma to emphasise just how problematic court cases are as a way of accessing slave women's experiences of violence. What we have are linear narratives which were arranged by court officials in a manner that they deemed to be logical and that concluded with confessions of guilt. ${ }^{24}$ The very nature of trauma, however, renders it antithetical to causality and linearity. It is in historical fiction that authors are able to question notions of linear teleology and causality and thus to gain a deeper understanding of the experiences of women who were traumatised by both the broader system of slavery and by the threat and reality of violent bodily assaults. Considering the mutual interdependence of fiction and testimony, it emerges that a literary reading of court records might be more than merely useful. Indeed, it can become necessary to achieve a more comprehensive understanding.

\section{The Gendered Nature of the Cape Colony in the Eighteenth Century}

In numerical terms, the Cape in the eighteenth century was a male-dominated society. ${ }^{25}$ Over the course of the century, the white population at the Cape moved closer to genderratio parity, but this was not the case for the slave population. ${ }^{26}$ Only 20 per cent of the

For more on these representational challenges, see S.J. Brison, Aftermath: Violence and the Remaking of a Self (Princeton: Princeton University Press, 2002); G.H. Hartman, 'On Traumatic Knowledge and Literary Studies', New Literary History, 26 (1995), 537-563; K. Oliver, Witnessing: Beyond Recognition (Minneapolis: University of Minnesota Press, 2001); J. Edkins, Trauma and the Memory of Politics (Cambridge: Cambridge University Press, 2003); L. Gilmore, The Limits of Autobiography: Trauma and Testimony (London: Cornell University Press, 2001); R. Leys, Trauma: A Genealogy (Chicago: Chicago University Press, 2000); J. Mitchell, 'Trauma, Recognition, and the Place of Language', Diacritics, 98 (1998), 121-133. R. Kennedy and J.T. Wilson, 'Constructing Shared Histories: Stolen Generations Testimony, Narrative Therapy and Address', in J. Bennett and R. Kennedy, eds, World Memory: Personal Trajectories in Global Time (New York: Palgrave Macmillan, 2003), 125. Kennedy and Wilson's work refers to the testimony of Australian Aborigines who were removed from their families as children and came to be known as Australia's 'stolen generation'. Even when trauma is experienced throughout a lifetime, it is by definition non-linear. This temporal elusiveness that goes to the heart of what trauma is, is what always complicates the articulation of trauma. When it comes to trauma, we can have access only to 'non-linear memory'. A number of theorists have emphasised the lack of temporal cohesion and linearity that characterise trauma narratives. See J. Berger, 'Trauma and Literary Theory', Contemporary Literature, 38 (1997), 569-582; C. Caruth, 'Trauma and Experience: Introduction', in C. Caruth, ed., Trauma: Explorations in Memory (London: The John Hopskins University Press, 1995), 3-12; A. Whitehead, Trauma Fiction (Edinburgh: Edinburgh University Press, 2004). Worden and Groenewald, Trials of Slavery, xxiv.

R. Ross, 'Oppression, Sexuality and Slavery at the Cape of Good Hope', Historical Reflections/ Réflections Historiques, 6 (1979), 421.

26 R. Ross, Beyond the Pale: Essays on the History of Colonial South Africa (Johannesburg: Witwatersrand University Press, 1993), 125-137. 
slave population consisted of women by the end of the eighteenth century. ${ }^{27}$ Van der Spuy points out that this was also a patriarchal society where political, social and economic power was concentrated in the hands of white men. ${ }^{28}$ The vulnerability of slave women was particularly acute since slaveholders legally owned women's bodies. ${ }^{29}$ In addition to the gendered oppression slave women suffered at the hands of slaveholders, they were exposed to gendered pressures emanating from other male slaves, who also came from societies that were male-dominated. ${ }^{30}$ While Van der Spuy rightly asserts that every specific instance of male domination is different and that one must avoid 'the trap of reducing everything to a single patriarchy, ${ }^{31}$ it seems clear that slave women in the Cape were confronted with what Belinda Bozzoli has referred to as a 'patchwork quilt of patriarchies'. ${ }^{32}$ Kerry Ward similarly points to the acute vulnerability of slave women in Cape society, since they were often victims of sexual and other types of assault at the hands of their masters as well as other slaves, while they had few legal or social tools with which to protect themselves. ${ }^{33}$

Researchers have argued that, in some cases, female slaves engaged in sexual relations with their masters in order to secure advantages for their children and for themselves. ${ }^{34}$ However, any assertion of slave women's 'choices' or 'opportunities' in this regard must take into account that any such 'choices' are made within a context of profound inequality, as outlined above. Fiona Vernal rightly asserts that it is highly problematic to try to determine whether a slave woman consented to sex with her owner, since the owner was in a position of such extreme power that female slaves often had no choice but to acquiesce to sexual advances. ${ }^{35}$ Susan Brownmiller analyses sex between white masters and black slaves in the American South. While the context is obviously very different from the eighteenth-century Cape, I do find some of her arguments useful when reading sexual liaisons at the Cape. She stops short of labeling all such contacts as rape, but goes on to note: 'But first, last and always, concubinage was a male-imposed condition: a bargain struck on male values exclusively, resting on a foundation of total ownership and control. ${ }^{36}$ Groenewald considers the phenomenon of concubinage in the eighteenth-century Cape and stresses that the profound vulnerability of the women who

$27 \quad$ Ross, 'Oppression', 421-433.

$28 \quad$ Van der Spuy, 'What Then was the Sexual Outlet', 47.

29 Scully, 'Rape, Race, and Colonial Culture', 350.

$30 \quad$ Van der Spuy, 'What Then was the Sexual Outlet', 47.

31 Ibid.

32 B. Bozzoli, 'Marxism, Feminism and South African Studies', Journal of Southern African Studies, 9 (1983), 139.

33 K. Ward, 'Defining and Defiling the Criminal Body at the Cape of Good Hope: Punishing the Crime of Suicide under Dutch East India Company Rule, circa 1652-1795', in S. Pierce and A. Rao, eds, Discipline and the Other Body: Correction, Corporality, Colonialism (London: Duke University Press, 2006), 50.

34 R. Shell, Children of Bondage: A Social History of the Slave Society at the Cape of Good Hope, 1652-1838 (Johannesburg: Witwatersrand University Press, 1994), 285-329; R. Brana-Schute, 'Approaching Freedom: The Manumission of Female Slaves in Suriname, 1760-1828', Slavery and Abolition, 10 (1989), 40-63. For more on these dynamics in the context of the nineteenthcentury Cape, see Scully, 'Rape, Race and Colonial Culture', and P. Scully, Liberating the Family: Gender and British Slave Emancipation in the Rural Western Cape, South Africa, 18251853 (Oxford: James Currey, 1997). Vernal, 'No Such Thing as a Mulatto Slave', 32.

S. Brownmiller, Against our Will: Men, Women and Rape (New York: Fawcett Books, 1975), 165. 
entered into such arrangements often resulted from poverty and inadequate social support systems. $^{37}$

When reading the experiences of slave women, it is important to consider how particular assumptions can be reflected in the choice of words. Ross points to the active sexual exploitation of slave women. He goes on to provide an example by noting that it was not unusual 'for a young white man to begin his sexual activity by seducing slave women, and the woman in question no doubt had little choice in the matter'. ${ }^{38}$ In the very next sentence, he refers to this practice as 'escapades' of the white men who engaged in it. ${ }^{39}$ Brownmiller describes seduction as an instance where 'the sexual goal may be accomplished without the use, or even the threat, of physical force, but the imposition of sex by an authority figure is hardly consensual or "equal"". ${ }^{40}$ Imposed sex that is not consensual is much better described as rape than as an 'escapade', with the word's connotations of an exciting adventure. I do not make this point to criticise Ross, whose important work clearly emphasises the lack of choice on the part of the slave woman. Rather, I wish to signal how a feminist reading of any text, including the narratives that I explore in the rest of the article, can reveal hidden meanings and problematise ways of articulating the experiences of women. ${ }^{41}$ The researcher must be wary of perpetuating discursive violence when describing women's bodily experiences of physical violation.

\section{Reading Women's Experiences in Selected Court Cases}

Historians have registered the problematic dynamics that come into play when reading court records. Worden and Groenewald note that court records describing crimes or suspected crimes were 'produced in highly unusual circumstances' that involved the pressures of speaking in the 'highly intimidating' environment of a court of law. ${ }^{42}$ Pam Scully explains that we can only access these narratives through the chronological accounts that were formulated by colonial officials who were themselves influenced by

G. Groenewald, “"A Mother Makes No Bastard”: Family Law, Sexual Relations and Illegitimacy in Dutch Colonial Cape Town, c. 1652-1795', African Historical Review, 39 (2007), 70. Historians have yet to offer an in-depth account of the cultural practices and beliefs that slaves brought with them to the Cape and how these factors might have shaped their behaviour and expectations here. While some slave women might well have expected to better their situations through concubinage, my intention here is to emphasise the power imbalance of the context in which these women functioned. For an account of the power dynamics involved in sexual relations with slaves in Southeast Asia, see B. Watson Andaya, 'From Temporary Wife to Prostitute: Sexuality and Economic Change in Early Modern Southeast Asia', Journal of Women's History, 9 (1998), 11-34.

Ross, 'Oppression', 429.

For another example of a problematically cavalier description of sex that borders on rape, see O.F. Mentzel, Description of the Cape of Good Hope, Vol. 2, ed. H.L. Mandelbrote (Cape Town: Van Riebeeck Society, 1924), 110.

Brownmiller, Against our Will, 271.

Scully addresses the problem of historians who discuss rape as a metaphor for tension in a society rather than as an act of violence: see Scully, Liberating the Family. See also Van der Spuy, 'What Then was the Sexual Outlet' and J. Sharpe, 'The Unspeakable Limits of Rape: Colonial Violence and Counter-Insurgency', Genders, 10 (1991), 25-46.

Worden and Groenewald, Trials of Slavery, xviii. 
the ideology of their particular place and time. ${ }^{43}$ This ideology was very much shaped by racial and gendered assumptions. Although original voices are hushed as they pass through the multiple levels of archival records, I agree with Worden and Groenewald that the reader can learn a great deal by paying attention to the 'echoes' that these voices have left. ${ }^{44}$ The richest traces of slaves' experiences emerge when we read these records against the grain and between the lines. ${ }^{45}$

There are numerous court cases in which male slaves confess to attacking female slaves because they suspected infidelity. One such case is that of Anthonij van Goa. Anthonij stabbed Jannetie, whom he describes as 'my own wife when I lived there'. ${ }^{4}$ Before reading the case, one must consider exactly how legal procedure and sentencing operated in the context of the eighteenth-century Cape. The dynamics differ significantly from the contemporary legal format where a prosecutor asks a question and a defendant answers the question that was posed. Rather, the prosecutor, who was not present during the interrogation, formulated questions on the basis of available evidence. After the accused had responded to the questions, an officer of the court arranged the questions and answers in a sequence that he found to be logical and chronological. ${ }^{47}$ I thus read the available records as a reflection of the gendered assumptions of both the courts and the defendants.

When the court asks Anthonij how he wounded Jannetie, he first provides a justification of his actions and then goes on to describe the assault:

The meijd [slave woman] had sworn I will never take another man for as long as you live, yet when he saw that she was lying with another man, then my heart ached, I then pushed away the jongen [slave man] and I stabbed her with a knife in the abdomen. ${ }^{48}$

In response to the question as to 'why' he did this, he answers 'because she had a relationship with another man', and he also admits that it was his intention to kill her. In her analysis of Robert Shell's work, Van der Spuy notes that, when male slaves' rage and

43

44

P. Scully, 'Narratives of Infanticide in the Aftermath of Slave Emancipation in the NineteenthCentury Cape Colony, South Africa', Canadian Journal of African Studies, 30 (1996), 94.

Worden and Groenewald, Trials of Slavery, xix. For more on the layered nature of archival records and its implications for reading such records, see A.L. Stoler and F. Cooper, 'Between Metropole and Colony: Rethinking a Research Agenda', in A.L. Stoler and F. Cooper, eds, Tensions of Empire: Colonial Cultures in a Bourgeois World (Berkeley: University of California Press, 1997), 1-56; M.R. Trouillot, Silencing the Past: Power and the Production of History (Boston: Beacon Press, 1995); A.L. Stoler, Carnal Knowledge and Imperial Power: Race and the Intimate in Colonial Rule (Berkeley: University of California Press, 2002); J.A. Bastian, 'Reading Colonial Records through an Archival Lens: The Provenance of Place, Space and Creation', Archival Science, 6 (2006), 267-284; A.L. Stoler, Along the Archival Grain: Epistemic Anxieties and Colonial Common Sense (Princeton: Princeton University Press, 2009).

For a theoretical discussion of the possibilities and pitfalls of this approach, see G. Levi, 'On Microhistory', in P. Burke, ed., New Perspectives on Historical Writing (Cambridge: Polity Press, 2001) and C. Ginzburg, Clues, Myths, and the Historical Method (Baltimore: The Johns Hopkins University Press, 1992). See also N. Zemon Davis, Fiction in the Archives: Pardon Tales and their Tellers in Sixteenth-Century France (Stanford: Stanford University Press, 1990) and N. Zemon Davis, The Return of Martin Guerre (Harvard: Harvard University Press, 1983).

Worden and Groenewald, Trials of Slavery, 93.

Ibid., xxiv.

Ibid., 93-94. 
jealousy manifested in violent outbursts, the resultant victims of rape and murder tended to be slaves rather than slave owners. ${ }^{49}$ Interestingly, in Anthonij's case, his rage seems to be solely directed at Jannetie, as he pushed the jongen aside and focused his attack on her. His repeated justification of the attack reflects the patriarchal tradition of blaming the victim for gender violence. The implication is that, had Jannetie not been unfaithful, he would not have attacked her. Van der Spuy's work is useful in reading this case as she makes the important point that '[r]ape and other crimes of violence, whether against women or men, need bear no relation to sex ratios and theories about physical sexual deprivation and frustration'. ${ }^{50}$ Instead, gender violence is about the desire to exert power and to affirm authority. ${ }^{51}$ From a feminist point of view, what happens in the personal space of the home and in relationships is of political importance. Anthonij's attack on Jannetie must thus be read as a fundamentally political act. Whether Anthonij attacked her to gain a sense of power and autonomy in a system that denied him these traits or whether he had other reasons, Jannetie's body became the site on which his psychological needs were played out. While both of their bodies were owned by the master, he seemed to be asserting ownership of Jannetie's body as well with his use of two terms of ownership when he calls her as 'my own wife'.

The theme of a male slave who attacks a female slave because he was 'driven by the jealousy of love' also crops up in the case of Januarij van Boegies. ${ }^{52}$ Statements from both the victim, Clara van Macassar, and her attacker, Januarij, are available. The violence was sparked when Januarij saw the slave Augustus rocking the cradle of Clara's crying baby. One can speculate over the reasons for Januarij's violent reaction to the seemingly innocuous act of comforting a child. It does, however, appear that he linked Augustus's presence near the cradle to suspicions about Clara's fidelity as he asked Clara what Augustus 'had to do with her'. ${ }^{53}$ The sexual vulnerability of slave women and the instability of family units could have led Januarij to react to the 'tenuousness of paternity'. ${ }^{54}$ A broad feminist definition would describe patriarchy as 'the manifestation and institutionalization of male dominance over women and children in the family and the extension of male dominance over women in society in general'. ${ }^{5}$ The ownership of children, as secured through paternity, is a central organising tenet of patriarchy. Slave descent was matrilineal, and the legal nature of slavery meant that slave fathers had no rights to their children. This additional insecurity may have added to the violence with which a man like Januarij reacted in this situation. Although slave men were themselves oppressed by the system of slavery, patriarchy allowed them to exert some control over slave women. While this control may have been severely limited, its importance to men who had few other avenues for asserting masculine domination should not be underestimated. The intertwined nature of paternity and patriarchy might help to explain Januarij's over-reaction when he saw another man near his lover's child.

\footnotetext{
$49 \quad$ Van der Spuy, 'What Then was the Sexual Outlet', 45.

Ibid., 47.

Ibid.

Worden and Groenewald, Trials of Slavery, 328.

Ibid.

N. Worden, Slavery in Dutch South Africa (Cambridge: Cambridge University Press, 1985), 58; P. Wald, Constituting Americans: Cultural Anxiety and Narrative Form (Durham, NC: Duke University Press, 1995), 159.

55 G.H. Lerner, The Creation of Patriarchy (New York: Oxford University Press, 1986), 29.
} 
The case sheds further light on the gendered pressures that slave women faced, particularly those who were mothers. Clara herself was unable to comfort her crying child because she 'was busy dressing the youngest son of her late owner'. ${ }^{56}$ Van der Spuy has highlighted the struggles of wet nurses who also had to care for their own babies. ${ }^{57}$ Slave women who worked in the houses of their owners faced similar challenges, as their domestic duties could prevent them from taking care of their own children's needs. Clara clearly had to negotiate her relationship with her child in a context where her ability to mother was severely constrained. She was unable to perform the most basic maternal act of soothing a crying baby because she had to prioritise the child of her owner. When she 'became frightened' because she realised that an attack was imminent, she tried to flee 'with her child on the arm' while also taking 'the child of her late owner by its hand'. It was 'while she was busy lifting the said child of her owner through the window to her in the street' that Januarij struck her with a parrang from inside the room. ${ }^{58}$ Once again, Clara was unable to ensure the safety of her own child because she also tried to remove the owner's child from danger.

Januarij's statement reveals a number of justifications for his violent actions, all of which were shaped by gendered assumptions. He notes that he was 'driven by the jealousy of love' and that he had been jealous of Augustus for a 'considerable time'. After Augustus forbade Januarij from speaking to Clara, Januarij felt 'provoked' and 'went to the back yard with the intention to get there a piece of firewood with which to beat the said meijd Clara'. ${ }^{59}$ Interestingly, he talks of his anger at seeing Augustus rocking the cradle and he mentions feeling provoked by Augustus's comment. Yet he seems to transfer his anger from Augustus and only talks of his intention to beat Clara when he went in search of a weapon. Later in the statement, he declares 'that he had not been of the intention to murder either the said meijd Clara, nor the slave Augustus, but only [emphasis added] to beat the meijd Clara'. Clara's body appears to be held solely responsible for his feelings of jealousy. Van der Spuy argues that it was not uncommon for slave men to attempt to safeguard the right of exclusive access to specific women within their social groups and, when they were unable to do so, violence against women frequently erupted. ${ }^{60}$ His actions thus reflected the common patriarchal assumption that women were responsible for men's sexuality and for the control thereof. ${ }^{61}$ While patriarchy is not a monolithic or static construct, this is one of the tenets that is remarkably pervasive. If Augustus felt any attraction for Clara, Januarij holds Clara rather than Augustus responsible for these sexual feelings.

The specific challenges facing slave mothers also emerge in the case brought against the slave owner Francois de Wet. ${ }^{62}$ The case followed a complaint by the slave David van de Caab against De Wet, alleging that De Wet caused the deaths of the

\footnotetext{
$56 \quad$ Worden and Groenewald, Trials of Slavery, 327.

$57 \quad$ Van der Spuy, 'What Then was the Sexual Outlet', 53. For more on slave wet nurses and nannies see also Shell, Children of Bondage, 304-312.

Worden and Groenewald, Trials of Slavery, 327.

Ibid., 328-329.

Van der Spuy, 'What Then was the Sexual Outlet', 47.

For an analysis of the continuing prevalence of this assumption, see the tellingly titled article by H. Moffett, "“These Women, They Force Us to Rape Them": Rape as Narrative of Social Control in Post-Apartheid South Africa', Journal of Southern African Studies, 32 (2006), 129-144. 
children of two female slaves, Jacomijn and Stijn. In his statement, David recalls De Wet's response whenever Jacomijn tried to comfort her crying child: 'You shouldn't think you're with De Waal where you can sit all day long with the child on your lap. ${ }^{63}$ Jacomijn had previously been staying on De Waal's farm 'to suckle [his] youngest child'. Rather than seeing her as a mother wanting to comfort her child, De Wet projects the stereotype of the lazy slave onto Jacomijn. According to Helen Carr, colonial discourse relegated both non-Europeans and women to a certain symbolic space. ${ }^{64}$ A slave woman such as Jacomijn was doubly inscribed with these symbolic markers because of her race and her gender. Carr notes that colonialism constructed them as "passive, child-like, unsophisticated, needing leadership and guidance, described always in terms of lack - no initiative, no intellectual powers, no perseverance'. ${ }^{65}$ If these are the representational scripts that De Wet was drawing on, it is little wonder that he saw Jacomijn as someone who wanted to sit about 'all day long'. There is no recognition of the multiple labour burdens she had to carry as a slave, as a mother and as a woman.

It is very difficult to comprehend fully the desperation of a mother who is unable to care for and protect her child, but when one tries to imagine the powerlessness that a woman would feel in such a situation, one can begin to understand Jacomijn's reactions. After repeatedly being forbidden to comfort her child, Jacomijn confronts De Wet with the following words: 'At Sieur De Waal's I at least always had somebody to look after my child, but now there's nobody; one day she will cry herself to death. ${ }^{66}$ Jacomijn is here probably referring to 'other-mothering', which was the 'practice whereby friends, family and neighbours shared childcare responsibilities with the biological mother' ${ }^{67}$ On De Wet's farm, however, it seems that Jacomijn was denied even this network of support. Jacomijn's articulation of her concern for her child angered De Wet to such an extent that he attacked her, as well as the child she was holding, with a sjambok. The child died that same night. Jacomijn was no more able to protect her child than she was to safeguard her own body against violence.

Jacomijn's desperation is further revealed by the fact that she confronted her owner even though she was most likely aware of the violent misogyny he directed at his female slaves. Further on in the same statement, David talks about the experiences of his sister Stijn. A Khoisan labourer who was living on De Wet's farm accused Stijn of infecting him with a venereal disease. De Wet's reaction was to give Stijn 'who was already ill, but still up and about, a thrashing with a back sjambok' ${ }^{68}$ The statement notes that this beating took place 'immediately' after De Wet heard the accusation against Stijn and that she died that same evening. The swiftness with which De Wet punished Stijn, rather than focusing on her accuser, who it could actually be proved had a venereal

$63 \quad$ Ibid., 601.

64 See also Stoler, Carnal Knowledge.

65 H. Carr, 'Woman/Indian, the "American" and his Others', in F. Barker et al, eds, Europe and its Others, Vol. 2 (Colchester: University of Essex Press, 1985), 50. The child-like attributes that colonialism attributed to non-Europeans also help to explain the designations meid and jongen. These terms literally translate as girls and boy and contributed to the infantilisation of people when applied to adult women and men.

$66 \quad$ Worden and Groenewald, Trials of Slavery, 601.

67 H. Altink, "I Did Not Want to Face the Shame of Exposure": Gender Ideologies and ChildMurder in Post-Emancipation Jamaica', Journal of Social History, 41 (2007), 369.

Worden and Groenewald, Trials of Slavery, 602. 
disease, suggests that De Wet holds very specific assumptions about female sexuality and responsibility. In the eighteenth century, women - especially indigenous colonised women - were constructed as sexually voracious, needing to be controlled and tamed. Ania Loomba notes that colonialism portrayed non-Europeans as lacking in morality and as sexually licentious. ${ }^{69}$ Sander Gilman further qualifies the representational intersections of race, gender and sexuality by explaining that black women were seen as possessing the attributes of prostitutes. ${ }^{70}$

In the same case, a statement by the Bastaard-Hottentot Anna provides a different perspective on the events in question. The purpose of this article is not to establish the 'truth' from available accounts, but to gain insight into the ways in which gender and violence shaped the lived reality of female slaves. To this end, my analysis of this statement will focus on Steijn's attempt to abort her four-month-old foetus. Although the exact prevalence of abortion and infanticide at the Cape can not be ascertained, historians have found that both practices did occur. ${ }^{71}$ The statement suggests that the motive for the attempted abortion was because Steijn wanted to go on a trip to Stellenbosch with her owners, but was forbidden from doing so by her juffrouw. Her pregnancy was cited as the reason for refusing her permission to travel. Steijn went about aborting the foetus by drinking 'vinegar mixed with gunpowder and soot from the chimney' in addition to a 'good quantity of brandy with lye, raisins and snake-skin'. ${ }^{72}$ This led to violent illness and constant vomiting. While we do not have access to Steijn's statement, it seems safe to assume that she was prompted to such extreme actions by more than her disappointment over a thwarted trip. The severe beatings that she had suffered at De Wet's hands, as well as the beatings of Jacomijn and Jacomijn's child, meant that she was located in a space where she was well aware of the complete vulnerability of her body. She must also have known that her inability to protect her own body from violence would extend to her child. While Steijn's voice is silent, Yvette Christiansë allows readers to hear the experiences of another slave woman who committed infanticide in her slave post-narrative Unconfessed. The article will now turn to the ways in which such fictionalised narratives can 'fill in the blanks that the slave narrative left' ${ }^{73}$

\section{Reading a Woman's Experiences in a Cape Post-Narrative}

Unconfessed is Christiansë's fictionalised account of the story of Sila van den Kaap. Sila's character is based on a Cape slave woman whose life spanned the last part of the eighteenth century and the early nineteenth century. ${ }^{74}$ Unconfessed was inspired by

69

A. Loomba, Colonialism and Postcolonialism (London: Routledge, 1998), 158. For more on Cape authorities' 'concern' about the sexual immorality of Khoi women, see Groenewald, 'A Mother Makes No Bastard', 67-70.

S. Gilman, 'Black Bodies, White Bodies: Towards an Iconography of Female Sexuality in Late Nineteenth-Century Art, Medicine and Literature', in H.L. Gates, ed., Race, Writing and Difference (Chicago: Chicago University Press, 1985), 248.

Groenewald, 'A Mother Makes No Bastard', 80.

Worden and Groenewald, Trials of Slavery, 603.

T. Morrison, 'The Site of Memory', in W. Zinsser, ed., Inventing the Truth: The Art and Craft of Memoir (Boston: Houghton Mifflen, 1987), 193-194.

The Dutch East India Company (VOC) ruled the Cape Colony until 1795. For most of Sila's lifetime, the Cape was thus not under VOC rule. In 1823, the year in which Sila's court case took place, the British government started instituting a series of regulations meant to ameliorate the 
archival court records. Sila was sentenced to death in April 1823 after being convicted of killing her nine-year-old son, Baro. Sila's act of infanticide is linked to her realisation that as a slave woman her 'body has no say in what happens to it'. ${ }^{75}$ Her statement echoes the bodily vulnerability of women like Jannetie, Clara, Jacomijn and Steijn. Like these women, Sila is exposed to gendered pressures and violence that emanate from a variety of sources. Unlike the slave women in the court records, however, Sila is allowed to voice the impact that gender violence has on her life and her actions. Before continuing to an analysis of Sila's experiences of violence, the article will consider some of the representational dynamics that come into play with slave post-narratives.

A text such as Unconfessed is located in the space where history and literature as well as fact and fiction intersect, and it thus straddles boundaries and challenges genre classifications. $^{76}$ In the process, such texts reveal alternatives for representing history. Ansgar Nünning goes on to explain that historical fiction tends to exhibit many of the textual features that are common in postmodernist literature, including '[f]ragmentation, discontinuity, indeterminacy, plurality, metafictionality, heterogeneity, intertextuality, decentring [and] dislocation'. ${ }^{77}$ Historical fiction is often motivated by the desire to offer different versions of history, and it is especially eager to explore alternative histories from the perspective of people who have been marginalised in traditional historical accounts. In interviews about her novel, Christiansë expressed a similar wish to challenge silences and to flesh out the lived reality of a woman like Sila. ${ }^{78}$ Historical fiction has proved to be a particularly attractive tool for writers attempting a feminist articulation of women's experiences. When looking at the past from a feminist vantage point, such novels can depict and question the oppression of women in the past, while simultaneously challenging the obfuscation of women in the annals of history. Rather than being

plight of slaves. By 1826, Ordinance 19 established a Protector of slaves, with whom slaves could lodge complaints about their treatment and living conditions. See W. Dooling, "“The Good Opinion of Others": Law, Slavery and Community in the Cape Colony c. 1760-1830', in N. Worden and C. Crais, eds, Breaking the Chains: Slavery and its Legacy in the Nineteenth-Century Cape Colony (Johannesburg: Witwatersrand University Press, 1994), 25-43. It is the Protector of slaves who initiates a reconsideration of Sila's case and who ensures that she has a lawyer to represent her. This intervention results in Sila's death sentence being commuted to a lengthy term on Robben Island. Yet on Robben Island, Sila's ill treatment, in the form of rapes and beatings, continues. Although these factors changed the context of slavery from that which existed under VOC rule, Unconfessed indicates that the changes often failed to have a significant impact on Sila's lived experience. For example, when Sila is worried that her daughter Meisie will be removed from Robben Island, she reveals the following lack of trust in the Protector's ability to help her: 'The Protector? Where was he when I needed him? He has slaves of his own, I hear. So, tell me, what does he protect?': Christiansë, Unconfessed, 106. An exchange among a group of slaves suggests a similar lack of confidence that the British would improve their lives: 'He [Johannes] said there was talk of people who did not like slavery and they were pushing the English inkosi to make a law that would protect us ... If Theron beats any of us again, we can go to the governor. You should have heard us laugh. Roosje said, ja? And how do we get to the governor? I [Sila] said, we can ride in Oumiesies's carriage like ladies': Christiansë, Unconfessed, 171. Christiansë, Unconfessed, 134.

A. Nünning, 'Crossing Borders and Blurring Genres: Towards a Typology and Poetics of Postmodernist Historical Fiction in England since the 1960s', European Journal of English Studies, 1 (1997), 218-219.

Ibid.

Christiansë, 'Interview', 4. 
constrained by the paucity of evidence that is available in sources such as court records, the historical novel opens up a space where researchers can grapple with the inaccessibility of women's traumatic experiences while also confronting the gendered assumptions and the factors that make such experiences so representationally problematic.

Probably the most well-known example of historical fiction or slave postnarrative is Toni Morrison's Beloved. ${ }^{79}$ Like Unconfessed, this novel deals with a female slave's desperate act of infanticide. Morrison's text suggests that 'a fictional account of the interior life of a slave might be more historically "real" than actual documents, which were often written from the perspective of the dominant culture' ${ }^{80}$ In a similar vein, I would argue that Unconfessed can teach us more about the motivations that would lead a slave woman to kill her child than a court record's suggestion that an abortion was prompted by a slave's petulance when she could not go on an outing. Like Jannetie and Steijn, Sila was exposed to extensive physical and psychic trauma.

Christiansë traces Sila's life from the time she was taken from her childhood home in Mozambique and sold to a succession of owners in the Cape. She was first owned by Minister Neethling, who sold her to Hendrina 'Oumiesies' Jansen. Oumiesies promised Sila that she would be freed but, after her death, her son Theron destroyed her will and took Sila as his own. He sold Sila to the merchant Hancke who tricked her into working off her 'freedom price' and, after years of toiling to pay for her and her children's freedom, Hancke sold them to Jacobus Stephanus van der Wat of Plettenberg Bay. ${ }^{81}$ Although she had a number of children, the novel provides little detail about them, as Sila herself does not know where they are sent after they are sold. She gave birth to Carolina in 1810, Camies in 1813, Baro in 1814, Pieter, Meisie, Catherina and Debora, as well as a son who died soon after birth and was not named. While at Van der Wat's farm, Sila committed infanticide. After three years, her death sentence was commuted to a lengthy term of imprisonment on Robben Island. Unconfessed is a contemporary representation of Sila's life as a slave woman in the Cape, and Christiansë taps into the collective traumatic memory of slavery by using fiction to articulate the trauma of racial and gender oppression through the character of Sila.

Throughout Sila's narrative, the focus is on her desperate attempts to care for her children in a society that saw them as less than human. Separation from her children is an ever-present threat as the slave owners had the power to sell a woman's children to different owners. Even when Sila's children are with her, she has to mother in a context where her choices and powers are severely limited. She is no more able to protect her children than she is to safeguard her own body against violence ranging from brutal beatings to being raped by her owners and jailers. According to Mason, '[s]ociety did not applaud a master's sexual exploitation of his female slave, but it did everything to make it possible and almost nothing to prevent it' ${ }^{82}$ Rape made slavery a fundamentally gendered practice. Ultimately, it is Sila's inability to protect Baro from the same beatings she endured that leads to her act of infanticide. She reflects that she, 'a grown woman,

79 Morrison, T. Beloved (London: Vintage, 2004).

80 K. Chabot Davis, "Postmodern Blackness": Toni Morrison's Beloved and the End of History', Twentieth Century Literature, 44 (1998), 248.

Christiansë, Unconfessed, 108.

Mason, Social Death, 99. 
knew what it was to have bruises and how they hurt. He, being a boy, had bruises the same size as mine. ${ }^{, 83}$ Her own life has taught her that Baro faces a lifetime of pain as she wonders 'what will the next day bring? What will the years bring?' ${ }^{84}$ She can protect Baro from the violent Van der Wat only by 'sending [him] away'. ${ }^{55}$ Sila repeatedly uses this euphemism for the infanticide that reveals just how tragically limited her maternal power is. $^{86}$

After the scene in which Baro is beaten by Van der Wat, the neighbouring farmer De la Rey tells Sila that she 'must teach that boy to know his place'. ${ }^{87}$ In her analysis of African American women's literature of slavery, Laura Dawkins asserts that the 'duty [of] a black son's mother must be to curb his speech, stifle his spirit, and - ultimately - to deliver him into a social order that will destroy him'. ${ }^{88}$ Sila is not afraid to make sacrifices for her children as she rhetorically asks the dead Baro 'you know your mother would grab the edge of a blade for you? You know your mother would cut off her right hand to save you? And you know you are dearer to me than my own right hand?' ${ }^{89}$ What she cannot accept, however, is that she should sacrifice her children to a racist society where they will face a lifetime of physical and psychological pain and degradation.

Even as Sila does all she can to be a good mother, the novel reveals the extent to which her actions are judged and her choices are limited. When she becomes pregnant in prison and the superintendent demands an explanation from the guards who raped her, they respond by saying '[s]he is a very bad woman' 90 and Sila finds that she 'had no energy to deny this'. ${ }^{91}$ She was also raped many times by her previous owners Theron and Van der Wat, who 'came each night" ${ }^{92}$ and 'sweated on her'. ${ }^{93}$ She is powerless to stop these men and these experiences teach her that '[a]fter all these years, [her] body still has no say in what happens to it' ${ }^{94}$ Although she is blameless, she rebukes herself for not knowing which one of her rapists fathered her children when she tells her unborn child '[b]aby, I am your mother. I am the one who should know all things about you because I was there, but I am already less than your mother because I do not know which one is your father. ${ }^{95}$ It seems that Sila has internalised the patriarchal assumption that women are responsible for the sexual excesses that men perpetrate on their bodies. The earlier analysis of the court cases reveals that such an assumption was as likely to be perpetuated by male slaves as by slave owners. By granting the reader access to Sila's interior monologues and experiences, Christiansë exposes the extent of Sila's vulnerability.

Sila's reflections also reveal how the gendered nature of slavery made it a very different system where women were concerned. The multiple labour burdens that De Wet

Christiansë, Unconfessed, 278.

Ibid.

Ibid., 240.

L. Dawkins, 'From Madonna to Medea: Maternal Infanticide in African American Women's Literature of the Harlem Renaissance', Literature Interpretation and Theory, 15 (2004), 223.

Christiansë, Unconfessed, 275.

Dawkins, 'From Madonna to Medea', 231.

Christiansë, Unconfesssed, 265.

Ibid., 8 .

Ibid., 9.

Ibid., 35 .

Ibid., 28.

Ibid., 133.

Ibid., 90 . 
seemed so unaware of in his comments about Jacomijn are expressed by Sila when she reacts to a male slave's suggestion that she should 'have strength'. ${ }^{96}$ The male slave Talmag says this by way of encouragement after Sila witnesses Baro being beaten by Van der Wat. All the slaves also expect that Sila will be severely punished because Baro embarrassed De Wet in front of friends. Sila asks herself: 'Strength? I did not see him going to be beaten. What did he know about strength? He worked the fields, he came back, he ate the food I had to cook, he lay down and slept. ${ }^{, 97}$ Sila also mentions that she 'cleaned, washed, ironed, sewed and cooked. And she thought about the ocean and heard it rush through the chambers of her ears at night as Van der Wat sweated on her, and Jeptha and Talmag ground their teeth with rage in their hut. ${ }^{98}$ Christiansë is drawing on the rage that resulted from the psychological impotence that slave men felt because they were powerless to prevent sexual relations between slave women and owners. ${ }^{99}$ Once again, the narrative illustrates how this rage is projected onto the female victim of rape rather than being solely directed at the perpetrator/owner. Sila notes that Jeptha and Talmag 'spat' at her, and 'she knew the men were jealous and ashamed, and that was why their eyes went dull with hatred when they looked at her'. ${ }^{100}$

\section{Conclusion}

This article has shown the extent to which slave women's voices tend to be silenced in historical records. By reading such records for the gaps in the narratives, one can gain insight into the lived experience of the slave women whose stories are referred to in court cases of the eighteenth-century Cape Colony. Any such reading must, however, take into consideration how these court cases were shaped by the gendered assumptions of the men who testified, as well as of the officers of the court who compiled the records. The textual traces repeatedly reveal the vulnerability of female slave bodies, which often became the site on which both slave owners and male slaves enacted their power in the case of the former and their powerlessness in the case of the latter. When one pays attention to the gaps in the narrative, it emerges that 'the silence in some ways stenciled out the conditions' in which slave women lived. In these court records, the silenced voices of the slave women who had been victims of violence can thus be read as enacting rather than concealing the truth of their lives. ${ }^{101}$ The trauma of slavery precludes the representation of its history as a coherent and linear series of events. The layered trauma that attends the vulnerable and violated bodies of female slaves renders their stories all the more elusive. In the post-narrative of Christiansë, the author attempts to tell one slave woman's story in all its incoherence and ambiguity and, in the process, allows the reader a glimpse into her lived experience in a way at which court records can only hint.

\section{References}

\begin{tabular}{ll}
\hline 96 & Ibid., 275. \\
97 & Ibid. \\
98 & Ibid., 28. \\
99 & Van der Spuy, 'What Then was the Sexual Outlet', 47. \\
100 & Christiansë, Unconfessed, 27. \\
101 & Christiansë, 'Interview', 4.
\end{tabular}


Abrahams, Y., 'Disempowered to Consent: Sara Bartman and Khoisan Slavery in the Nineteenth-Century Cape Colony and Britain', South African Historical Journal, 35 (1996), 89-114.

Altink, H., "I Did Not Want to Face the Shame of Exposure": Gender Ideologies and Child-Murder in Post-Emancipation Jamaica', Journal of Social History, 41 (2007), 355-387.

Bastian, J.A., 'Reading Colonial Records through an Archival Lens: The Provenance of Place, Space and Creation', Archival Science, 6 (2006), 267-284.

Benadé, T., Kites of Good Fortune (Cape Town: David Philip, 2004).

Berger, J., 'Trauma and Literary Theory', Contemporary Literature, 38 (1997), 569-582.

Bozzoli, B., 'Marxism, Feminism and South African Studies', Journal of Southern African Studies, 9 (1983), 139-171.

Bradford, H., 'Women, Gender and Colonialism: Rethinking the History of the British Cape Colony and its Frontier Zones, c. 1806-70', The Journal of African History, 37 (1996), 351-370.

Brana-Schute, R., 'Approaching Freedom: The Manumission of Female Slaves in Suriname, 1760-1828', Slavery and Abolition, 10 (1989), 40-63.

Brink, A., Instant in the Wind (London: William Morrow, 1977).

Brison, S.J., Aftermath: Violence and the Remaking of a Self (Princeton: Princeton University Press, 2002).

Brownlee, R., Garden of the Plagues (Cape Town: Human and Rousseau, 2005).

Brownmiller, S., Against our Will: Men, Women and Rape (New York: Fawcett Books, 1975).

Carr, H., 'Woman/Indian, the "American" and his Others', in Barker, F. et al, eds, Europe and its Others, vol. 2 (Colchester: University of Essex Press, 1985).

Caruth, C., 'Trauma and Experience: Introduction', in Caruth, C., ed., Trauma: Explorations in Memory (London: The John Hopskins University Press, 1995), 312.

Chabot Davis, K., "Postmodern Blackness": Toni Morrison's Beloved and the End of History', Twentieth Century Literature, 44 (1998), 242-260.

Chase-Riboud, B., Hottentot Venus (New York: Anchor Books, 2004).

Christiansë, Y., Unconfessed (Cape Town: Kwela Books, 2006).

Christiansë, 'Interview', Y., Available at http://www.pbs.org/kcet/tavissmiley/archive/200702/20070215_christianseuml.ht $\mathrm{ml}$ [accessed 29 May 2009].

Crenshaw, K., 'Mapping the Margins: Intersectionality, Identity Politics, and Violence against Women of Color', Stanford Law Review, 43 (1991), 1241-1299.

Crais, C. and Scully, P., Sara Baartman and the Hottentot Venus: A Ghost Story and a Biography (Johannesburg: Wits University Press, 2009).

Dawkins, L., 'From Madonna to Medea: Maternal Infanticide in African American Women's Literature of the Harlem Renaissance', Literature Interpretation and Theory, 15 (2004), 223-240.

Derrida, J., Demeure: Fiction and Testimony, trans. E. Rottenberg (Stanford: Stanford University Press, 2000). 
Dooling, W., "'The Good Opinion of Others": Law, Slavery and Community in the Cape Colony c. 1760-1830', in N. Worden and C. Crais, eds, Breaking the Chains: Slavery and its Legacy in the Nineteenth-Century Cape Colony (Johannesburg: Witwatersrand University Press, 1994), 25-43.

Edkins, J., Trauma and the Memory of Politics (Cambridge: Cambridge University Press, 2003).

Gilman, S., 'Black Bodies, White Bodies: Towards an Iconography of Female Sexuality in Late Nineteenth-Century Art, Medicine and Literature', in H.L. Gates, ed., Race, Writing and Difference (Chicago: Chicago University Press, 1985), 221261.

Gilmore, L., The Limits of Autobiography: Trauma and Testimony (London: Cornell University Press, 2001).

Ginzburg, C., Clues, Myths, and the Historical Method (Baltimore: The Johns Hopkins University Press, 1992).

Gqola, P.D., "Like Three Tongues in One Mouth": Tracing the Elusive Lives of Slave Women in (Slavoctratic) South Africa', in N. Gasa, ed., Women in South African History: They Remove Boulders and Cross Rivers (Cape Town: HSRC Press, 2007), 21-41.

Groenewald, G., 'Panaij van Boegies: Slave - Bandiet-Caffer', Quarterly Bulletin of the National Library of South Africa, 59 (2005), 50-62.

Groenewald, G., “"A Mother Makes No Bastard”: Family Law, Sexual Relations and Illegitimacy in Dutch Colonial Cape Town, c. 1652-1795', African Historical Review, 39 (2007), 58-90.

Hartman, G.H., 'On Traumatic Knowledge and Literary Studies', New Literary History, 26 (1995), 537-563.

Holmes, R., The Hottentot Venus: The Life and Death of Saartjie Baartman: born 1789 buried 2002 (London: Bloomsbury, 2007).

Hutcheon, L., A Poetics of Postmodernism: History, Theory, Fiction (New York: Routledge, 1988).

Jacobs, R., The Slave Book (Cape Town: Kwela Books, 2007).

Kennedy, R. and Wilson, J.T., 'Constructing Shared Histories: Stolen Generations Testimony, Narrative Therapy and Address', in J. Bennett and R. Kennedy, eds, World Memory: Personal Trajectories in Global Time (New York: Palgrave Macmillan, 2003), 119-139.

Koolhof, S. and Ross, R., 'Upas, September and the Bugis at the Cape of Good Hope: The Context of a Slave's Letter', Archipel, 70 (2005), 281-308.

Laub, D., 'Bearing Witness or the Vicissitudes of Listening', in S. Felman and D. Laub, eds, Testimony: Crises of Witnessing in Literature, Psychoanalysis and History (London: Routledge, 1992), 57-74.

Lerner, G.H., The Creation of Patriarchy (New York: Oxford University Press, 1986).

Levi, G., 'On Microhistory', in P. Burke, ed., New Perspectives on Historical Writing (Cambridge: Polity Press, 2001), 97-119.

Leys, R., Trauma: A Genealogy (Chicago: Chicago University Press, 2000).

Loomba, A., Colonialism and Postcolonialism (London: Routledge, 1998).

Malherbe, V.C., 'In Onegt Verwekt: Law, Custom and Illegitimacy in Cape Town, 18001840', Journal of Southern African Studies, 31 (2005), 163-185. 
Mason, J., Social Death and Resurrection: Slavery and Emancipation in South Africa (Charlottesville, VA: University of Virginia Press, 2003).

Mentzel, O.F., Description of the Cape of Good Hope, ed. H.J. Mandelbrote (Cape Town: Van Riebeeck Society, 1924).

Mink, L., 'History and Fiction as Modes of Comprehension', New Literary History, 1 (1970), 541-558.

Mitchell, J., 'Trauma, Recognition, and the Place of Language', Diacritics, 98 (1998), $121-133$.

Moffett, H., "“These Women, They Force Us to Rape Them": Rape as Narrative of Social Control in Post-Apartheid South Africa', Journal of Southern African Studies, 32 (2006), 129-144.

Morrison, T., 'The Site of Memory', in W. Zinsser, ed., Inventing the Truth: The Art and Craft of Memoir (Boston: Houghton Mifflen, 1987).

Morrison, T., Beloved (London: Vintage, 2004).

Murray, J., 'When Good Mothers Kill: A Representation of Infanticide', Agenda, 76 (2008), 32-41.

Murray, K., 'Fiction, History and Empirical Reality', Critical Inquiry, 1, 2 (1974), 335360.

Newton-King, S., Masters and Servants on the Cape Eastern Frontier, 1760-1803 (Cambridge: Cambridge University Press, 1999).

Nünning, A., 'Crossing Borders and Blurring Genres: Towards a Typology and Poetics of Postmodernist Historical Fiction in England since the 1960s', European Journal of English Studies, 1 (1997), 217-238.

Oliver, K., Witnessing: Beyond Recognition (Minneapolis: University of Minnesota Press, 2001).

Penn, N., Rogues, Rebels and Runaways: Eighteenth-Century Cape Characters (Cape Town: David Philip Publishers, 1999).

Penn, N., 'The Wife, the Farmer and the Farmer's Slaves: Adultery and Murder on a Frontier Farm in the Eighteenth Century', Kronos, 28 (2002), 1-20.

Ross, R., 'Oppression, Sexuality and Slavery at the Cape of Good Hope', Historical Reflections/Réflections Historiques, 6 (1979), 421-433.

Ross, R., Beyond the Pale: Essays on the History of Colonial South Africa (Johannesburg: Witwatersrand University Press, 1993).

Samuelson, M., 'Lose you Mother, Kill you Child: The Passage of Slavery and its Afterlife in Narratives by Yvette Christiansë and Saidiya Hartman', English Studies in Africa (forthcoming).

Samuelson, M., "Castaways" and "Generations": Yvette Christiansë's Oceanic Genealogies and the Colonial Archive' (unpublished paper).

Scully, P., 'Rape, Race, and Colonial Culture: The Sexual Politics of Identity in the Nineteenth-Century Cape Colony, South Africa', American Historical Review, 100 (1995), 335-359.

Scully, P., 'Narratives of Infanticide in the Aftermath of Slave Emancipation in the Nineteenth-Century Cape Colony, South Africa', Canadian Journal of African Studies, 30 (1996), 88-105.

Scully, P., Liberating the Family: Gender and British Slave Emancipation in the Rural Western Cape, South Africa, 1823-1853 (Portsmouth, NH: Heinemann, 1997). 
Sharpe, J., 'The Unspeakable Limits of Rape: Colonial Violence and CounterInsurgency', Genders, 10 (1991), 25-46.

Shell, R., ed., 'Slaves: An Essay by Samuel Eusebuis Hudson', Kronos, 9 (1984), 44-70.

Shell, R., Children of Bondage: A Social History of the Slave Society at the Cape of Good Hope, 1652-1838 (Johannesburg: Witwatersrand University Press, 1994).

Shiller, D., 'The Redemptive Past in the Neo-Historical Novel', Studies in the Novel, 29 (1997), 538-560.

Stoler, A.L. and Cooper, F., 'Between Metropole and Colony: Rethinking a Research Agenda', in A.L. Stoler and F. Cooper, eds, Tensions of Empire: Colonial Cultures in a Bourgeois World (Berkeley: University of California Press, 1997), $1-56$.

Stoler, A.L., Carnal Knowledge and Imperial Power: Race and the Intimate in Colonial Rule (Berkeley: University of California Press, 2002).

Stoler, A.L., Along the Archival Grain: Epistemic Anxieties and Colonial Common Sense (Princeton: Princeton University Press, 2009).

Thomson, K., "The Mistress will be Consumed": A Study of Slave Resistance in $18^{\text {th }}$ Century Cape Town', Historical Approaches, 2 (2003), 16-29.

Trouillot, M.R., Silencing the Past: Power and the Production of History (Boston: Beacon Press, 1995).

Turrell, R., 'The "Singular" Case of Mietjie Bontnaal, the Bushmanland Murderess', Journal of Southern African Studies, 29 (2003), 83-103.

Van der Spuy, P., 'Gender and Slavery: Towards a Feminist Revision', South African Historical Journal, 25 (1991), 184-195.

Van der Spuy, P., 'Slave Women and the Family in Nineteenth-Century Cape Town', South African Historical Journal, 27 (1992), 50-74.

Van der Spuy, P., 'A Collection of Discrete Essays with the Common Theme of Gender and Slavery at the Cape of Good Hope with a Focus on the 1820s' (MA thesis, University of Cape Town, 1993).

Van der Spuy, P., "What Then was the Sexual Outlet for Black Males?": A Feminist Critique of Quantitative Representation of Women Slaves at the Cape of Good Hope in the Eighteenth Century', Kronos, 23 (1996), 43-56.

Vernal, F., "No Such Thing as a Mulatto Slave": Legal Pluralism, Racial Descent and the Nuances of Slave Women's Sexual Vulnerability in the Legal Odyssey of Steyntje van de Kaap, c. 1815-1822', Slavery and Abolition, 29 (2008), 23-47.

Wald, P., Constituting Americans: Cultural Anxiety and Narrative Form (Durham, NC: Duke University Press, 1995).

Walsh, R., 'Fictionality and Mimesis: Between Narrativity and Fictional Worlds', Narrative, 11 (2003), 110-212.

Warhol, R.R. and Price Herndl, D., 'History', in R.R. Warhol and D. Price Herndl, eds, Feminisms: An Anthology of Literary Theory and Criticism (New Jersey: Rutgers University Press, 1997), 855-859.

Ward, K., 'Defining and Defiling the Criminal Body at the Cape of Good Hope: Punishing the Crime of Suicide under Dutch East India Company Rule, circa 1652-1795', in S. Pierce and A. Rao, eds, Discipline and the Other Body: Correction, Corporality, Colonialism (London: Duke University Press, 2006). 
Watson Andaya, B., 'From Temporary Wife to Prostitute: Sexuality and Economic Change in Early Modern Southeast Asia', Journal of Women's History, 9 (1998), 11-34.

White, H., Metahistory: The Historical Imagination in Nineteenth-Century Europe (Baltimore: John Hopkins University Press, 1973).

White, H., 'The Question of Narrative in Contemporary Historical Theory', History and Theory, 23 (1984), 1-33.

Whitehead, A., Trauma Fiction (Edinburgh: Edinburgh University Press, 2004).

Worden, N., Slavery in Dutch South Africa (Cambridge: Cambridge University Press, 1985).

Worden, N., 'New Approaches to VOC History in South Africa', South African Historical Journal, 59 (2007), 3-18.

Worden, N. and Groenewald, G., eds, Trials of Slavery: Selected Documents Concerning Slaves from the Criminal Records of the Council of Justice at the Cape of Good Hope, 1705-1794 (Cape Town: Van Riebeeck Society for the Publication of South African Historical Documents, 2005).

Zemon Davis, N., The Return of Martin Guerre (Harvard: Harvard University Press, 1983).

Zemon Davis, N., Fiction in the Archives: Pardon Tales and their Tellers in SixteenthCentury France (Stanford: Stanford University Press, 1990). 